\title{
Quantitative Analysis of the Impact of Microcredit for Women Microentrepreneurs
}

\author{
Aine Carolina ${ }^{1}$ and Sandro Carbal ${ }^{\#}$ \\ ${ }^{1}$ Colegio Etapa, Sao Paolo, Brazil \\ \#Advisor
}

$\underline{\text { ABSTRACT }}$

Microcredit has a fundamental role as a tool for financial inclusion. It is estimated that there are almost 50 million microentrepreneurs in Brazil, of which two-thirds are women. This work aims to analyze the impact of microcredit for women microentrepreneurs in comparison with men, based on data collected in northeastern Brazil in partnership Avante, a fintech specialized in microcredit. Data were collected from microentrepreneurs who had access to credit (treatment group) and those who did not have their credit granted (control group) so that they could be compared. The analysis was divided into two parts. In Part I, a descriptive statistical analysis of the collected data was performed. In Part II, some simplified causal inference techniques were applied to validate whether the impact of microcredit existed for women microentrepreneurs. The results give strong indications that women, despite having a lower income, grow more than men after access to microcredit. The annualized growth in income of women was $19.87 \%$, while that of men was $14.66 \%$.

\section{Introduction}

Microcredit has become an essential instrument for social inclusion because it allows small-scale business-owners from underserved communities worldwide to have access to working capital to develop their business. This may represent one of the few opportunities to get out of poverty (FILHO, 2019). Due to the size of their ventures, these small-scale business-owners are commonly called microentrepreneurs, and the financial services offered to them are called microfinance.

The idea of microfinance for microentrepreneurs emerged in 1980, with the Grameen Bank (ALESP..., 2008), the first microcredit institution founded in Bangladesh by Muhammad Yunus, winner of the 2006 Nobel Peace Prize. Under the influence of the Grameen Bank, Brazil was one of the first countries to adopt the practice of microcredit. In 1996, the BNDES National Bank for Economic and Social Development (BNDES) created the Popular Productive Credit Program to reach microentrepreneurs, including formal and informal ones. In 2005, the Brazilian government created the National Program of Oriented Productive Microcredit (PNMPO). Among the normative measures of the PNMPO, it was determined that the interest rate applied to microcredit loans must not be higher than $4.0 \%$ per month. Also, it regulated the use of the compulsory reserves in the central bank, allowing $2 \%$ of the total deposits to be used for microcredit.

In addition to government programs and incentives, the past few years have also seen an increase in fintechs, startups that use technology and data science to offer credit in a faster and more comprehensive way. Despite the PNMPO and the advent of fintechs, the potential microcredit market for microentrepreneurs is still particularly broad and unexplored in Brazil. Recent data from the government shows over 10 million individual microentrepreneurs (MEI) in 2020, which marks the highest ever achieved by the country. However, these MEIs represent only the group of formal entrepreneurs, that is, those holding a legally registered company and an official Fiscal Identification Number. 
Nevertheless, the total number of microentrepreneurs, including informal ones, is much higher. According to the GEM (Global Entrepreneurship Monitor), 2018, there are at least 47 million microentrepreneurs in Brazil. Of these, a relevant portion is made up of women. It is known that $70 \%$ of the world's low-income population is composed of women (ILO..., 1996). In the universe of micro-entrepreneurship, the participation of women keeps the same proportion. Therefore, microcredit has a fundamental role in reducing gender inequality.

This work aims to extrapolate the conceptual field and provide evidence of the participation of women in microentrepreneurship and quantify the impact of microcredit on their businesses, comparing that to the impact on businesses managed by male microentrepreneurs. This work analysed data from 8,722 microentrepreneurs in the Northeast of Brazil, in the states of Ceará (CE), Maranhão (MA), Pernambuco (PE) and Paraíba (PB). These comprise one of the lowest-income areas of the country. This work was organized into two parts. In Part I, we focus on descriptive statistics. We carry out investigative research to understand the main characteristics of microentrepreneurs, including geographic distribution, gender, age, business sector, and time of activity in the business. In Part II, we focus on inferential statistics. In a simplified way, our work compares microentrepreneur borrowers with a control group that did not have access to microcredit, to validate whether the growth effect of revenue caused by credit exists. Lastly, we compare this effect by segregating the results between men and women.

\section{PART I - Methodology}

We used data collected by a Brazilian fintech that specializes in microcredit. The company's credit granting process is based on a network of agents. These agents visit the microentrepreneurs equipped with tablets and register the information collected in the credit interviews. In carrying out this study, the credit interviews focused on the variables related to the microentrepreneur (gender, age, business income, total family income, and family expenses), to the business itself (business sector, time of activity in the business), and to the loan (rate, term, and value of the loan), in addition to geolocation data.

Out of the microentrepreneurs visited, $34.83 \%$ had their credit proposals approved by the company and their credit contract formalized. The features of the credit granted are indicated in Table 1. It is important to note that the majority of the credit borrowers are informal entrepreneurs and therefore do not have formal accounting. All business information, including revenues, was declared by the microentrepreneurs during the interviews and has not undergone any external validation. However, the credit agents are trained to perform the interviews. Also, agents are assessed and compensated based on the performance of their credit portfolio, that is, based on the level of delinquency of the borrowers. Thus, there are incentives in the process of credit concession, so that the data collected by the agents are consistent and as close as possible to reality.

Table 1. Characteristics of the microcredit contracts.

\begin{tabular}{l|l}
\hline Contract Feature & Value \\
\hline Loan range & $\mathrm{R} \$ 392,00$ to $\mathrm{R} \$ 21.800,00$ \\
\hline Average loan & $\mathrm{R} \$ 2844,20$ \\
\hline Monthly interest rate & $2,9 \%$ to $5,4 \%$ \\
\hline Range of instalments & 4 to 12 \\
\hline Average number of instalments & 7,86 \\
\hline
\end{tabular}

To carry out this study, the data set was cleaned and records with inconsistencies were removed. First, data rows with empty, null, and negative business revenues were discarded. Then, outlier records were removed applying the interquartile range (IQR) methodology. Considering Q1 and Q3, quartiles 1 and 3 respectively, and X the median of the observations, the lower $\left(L_{\text {lower }}\right)$ and upper $\left(L_{\text {upper }}\right)$ limits used for the outlier removal is shown in Equation 1. 
Equation 1: Interquartile range methodology for outlier removal.

$$
I Q R=Q_{3}-Q_{1}
$$

where,

$L_{\text {lower }}=X-1,5 \times I Q R$

$L_{\text {upper }}=X+1,5 \times I Q R$

\section{Part I - Results}

The results in Figure 1 show the geographic distribution of the microentrepreneurs studied in this work. As expected, participation is predominantly female, with more than two-thirds of the sample of microentrepreneurs analyzed being women. The time of activity of microentrepreneurs in their respective businesses is shown in Figures 6 and 7. The numbers indicate a long average time of activity in their business, which can indeed translate into the dominance of their areas of activity or stability in their business. It is important to emphasize that credit was offered only to microentrepreneurs with at least 12 months of experience, which contributes to the longer average time of activity.

The main business segments are shown in Figure 8. Notably, the largest segments are the cosmetics and the clothing ones, which are segments with female predominance. The male presence, on the other hand, is more robust in the supermarket segment. A slight discrepancy observed between male and female microentrepreneurs is related to the value of the credit granted, as shown in Figures 9 and 10. The value of the credit approved for women is, on average, $10.83 \%$ lower than that of men. This fact may be a direct consequence of the difference in revenue between men and women. As we saw in Figure 11, the average declared earnings of women is $R \$ 4,386.80$, while that of male microentrepreneurs is $R \$ 5,450.30$, that is, $24.2 \%$ higher. As the credit selection and approval process consider the financial capacity of the microentrepreneur, it is natural that those with higher revenues will receive bigger loans. Observe, however, that women have lower revenues even in the segments where they represent the majority. The Figure 12 shows the revenue compared by segment.

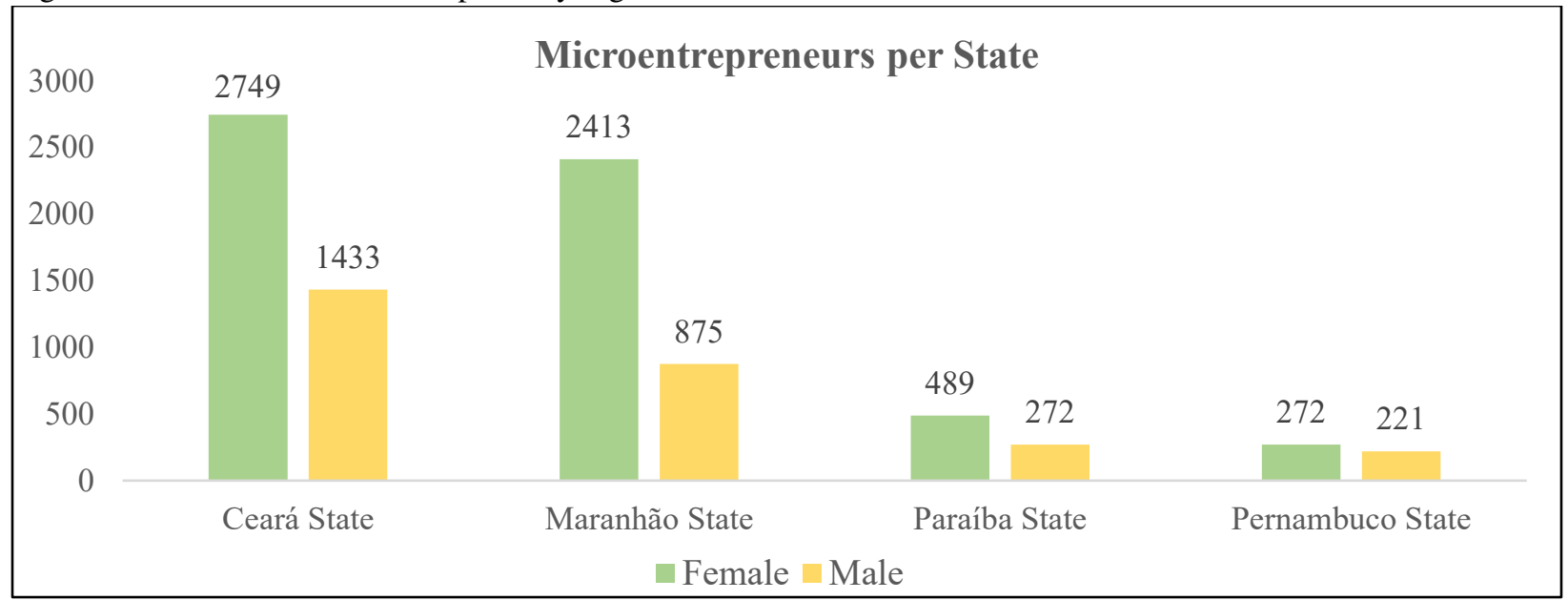

Figure 1. Distribution of customers by state. 


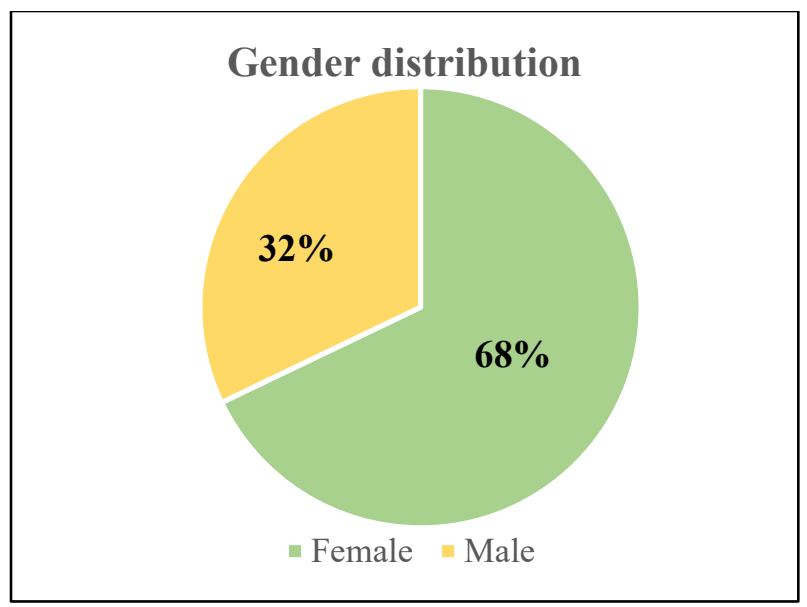

Figure 2. Participation per gender in the microcredit portfolio.

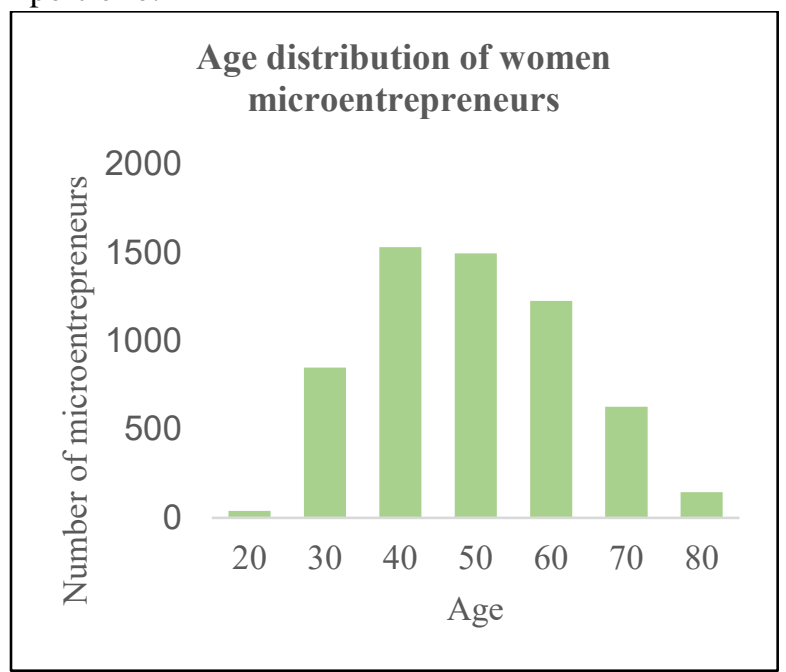

Figure 4. Age distribution of women microentrepreneurs.

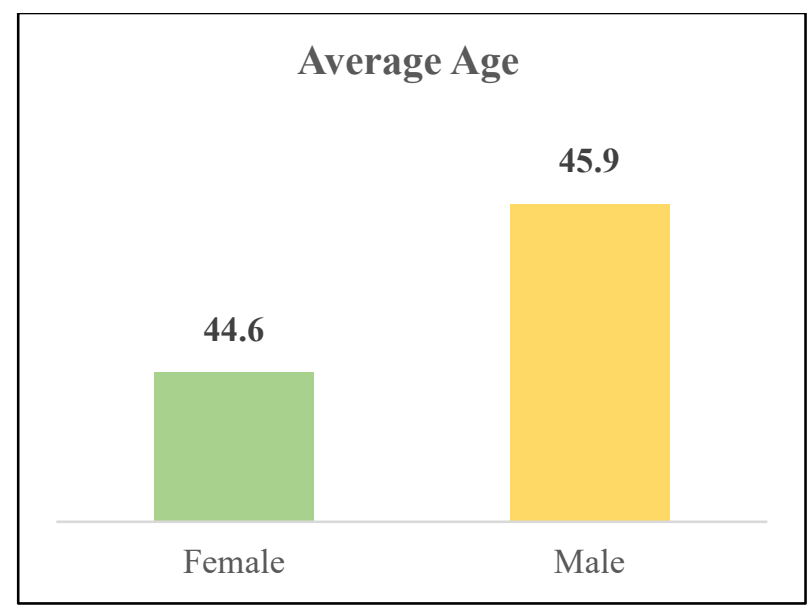

Figure 3. Average age of microentrepreneurs.

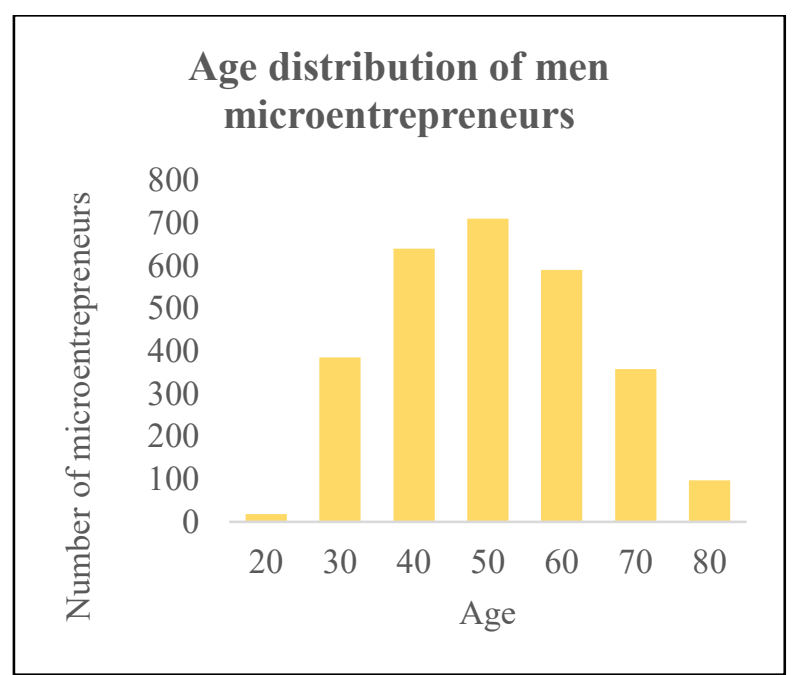

Figure 5. Age distribution of men microentrepreneurs.

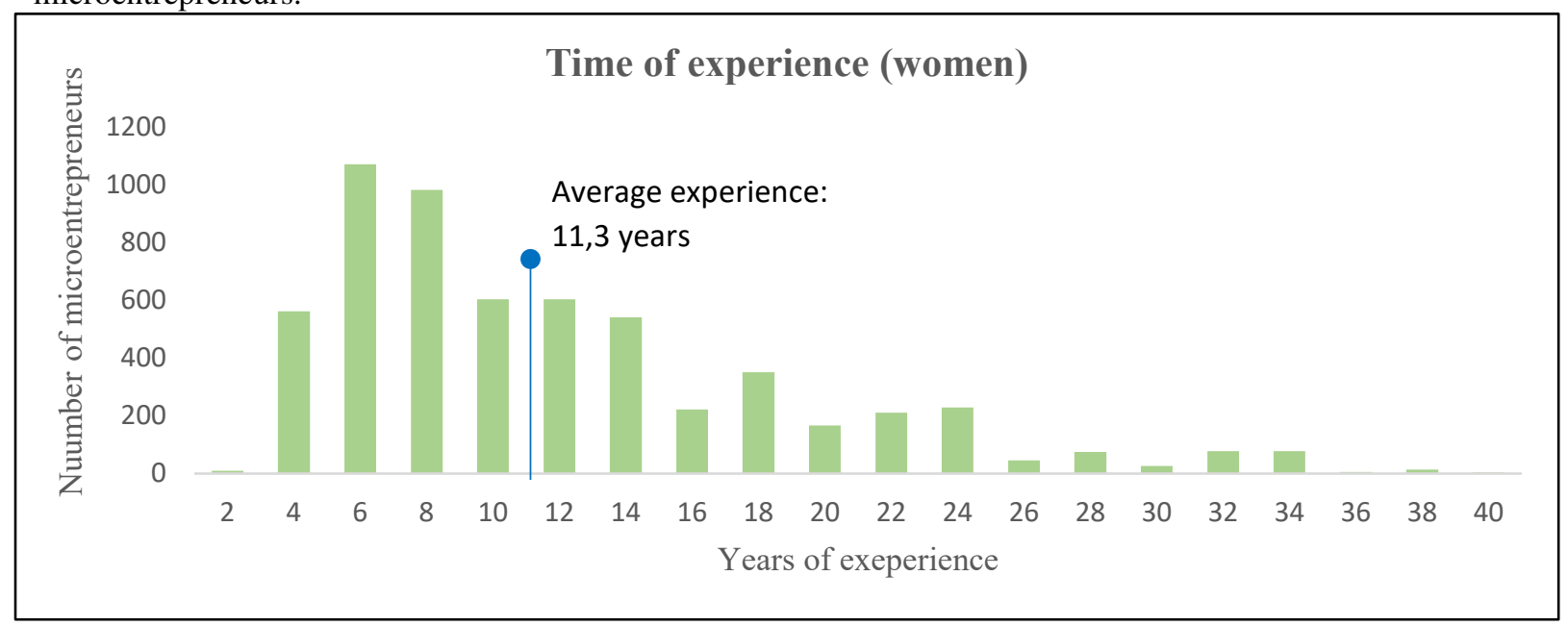

Figure 6. Length of time in the business of women microentrepreneurs. 


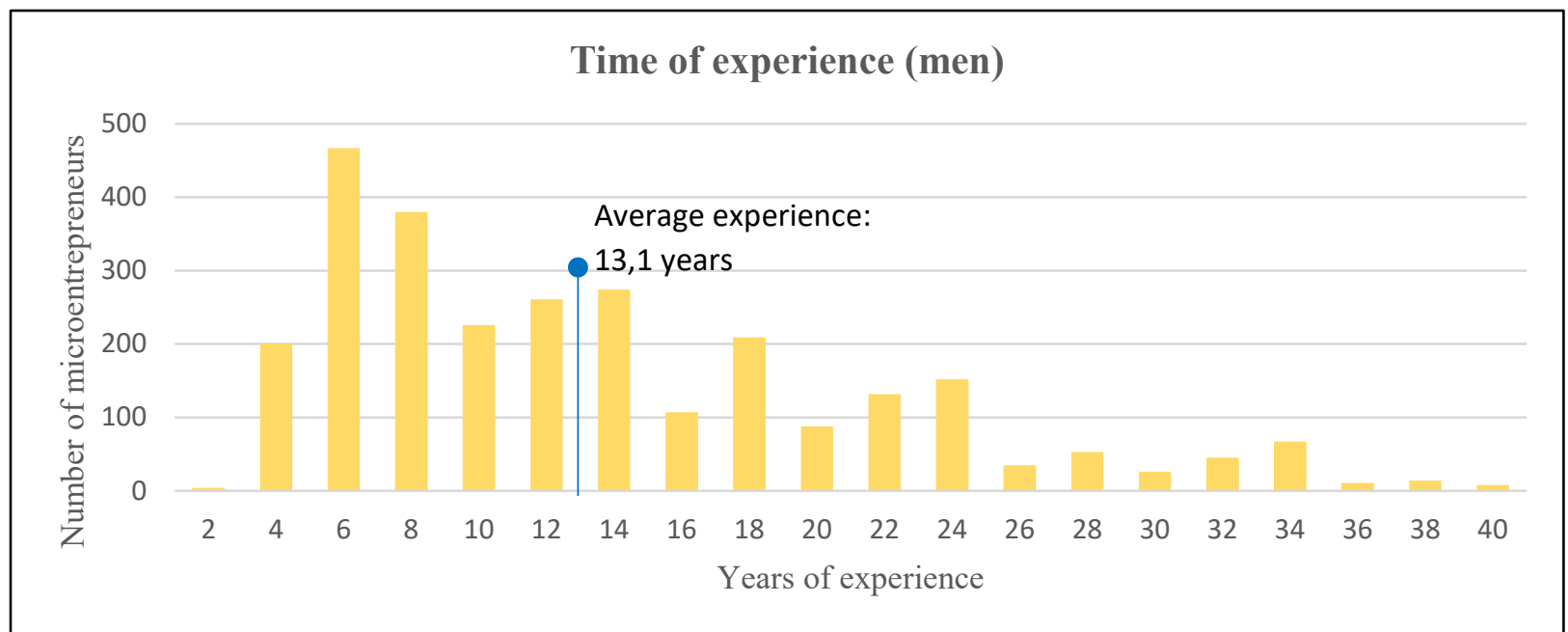

Figure 7. Length of time in the business of men microentrepreneurs. 


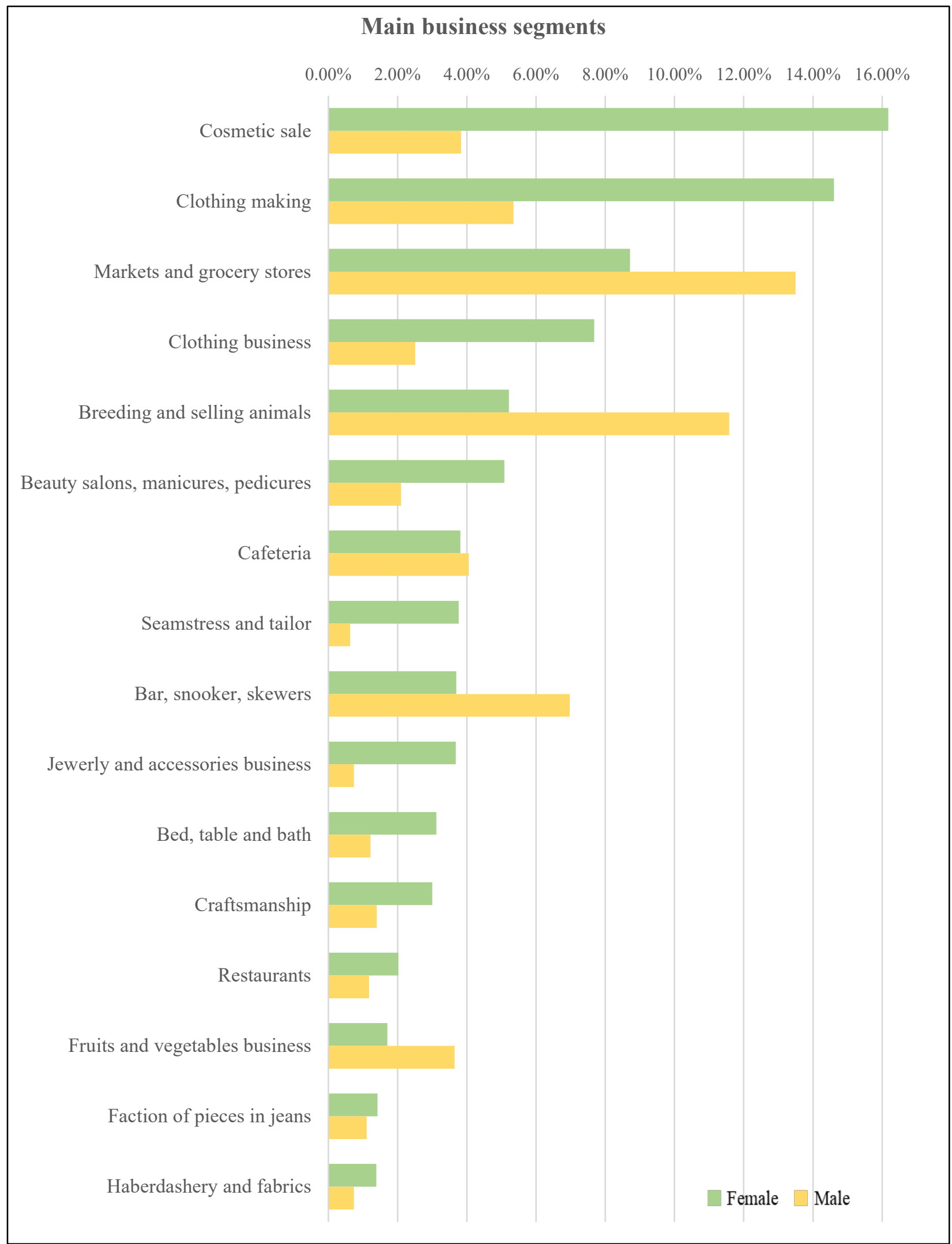

Figure 8. Main segments of activity of microentrepreneurs, segregated by gender. 


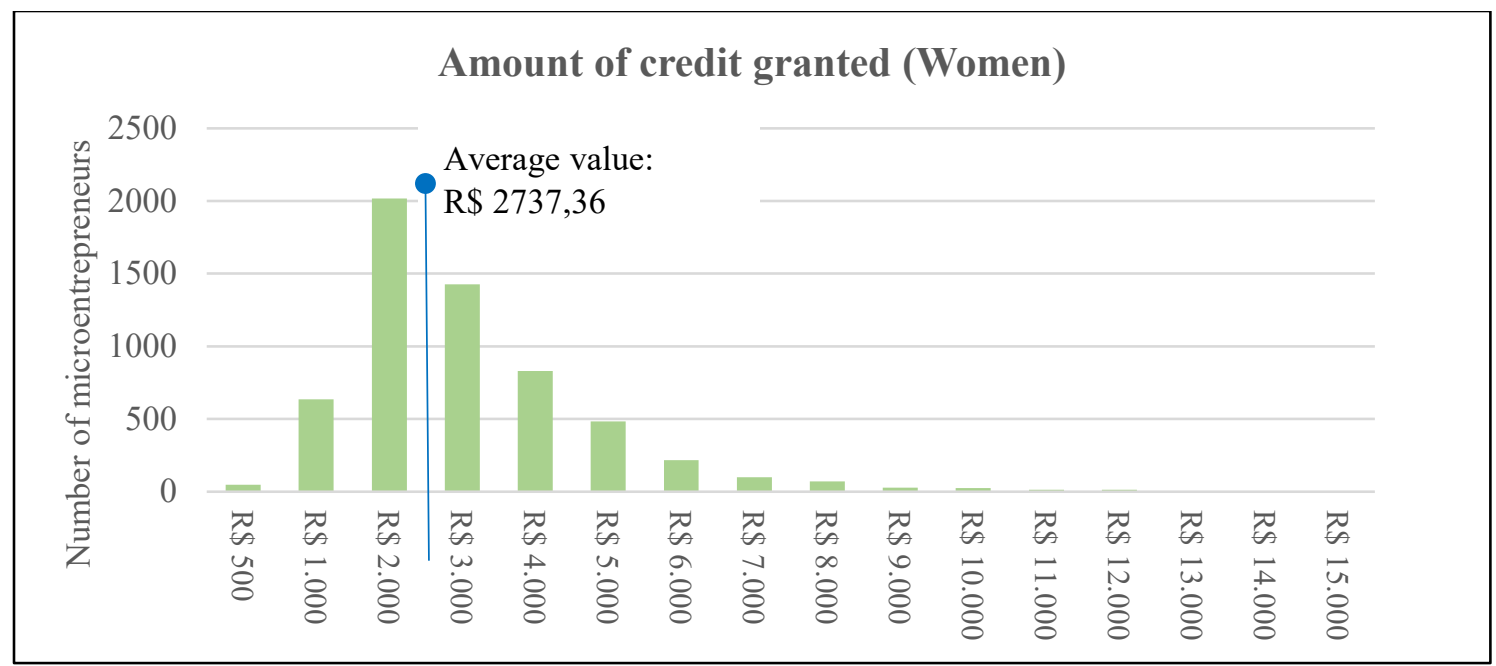

Figure 9. Amount of credit granted to women microentrepreneurs.

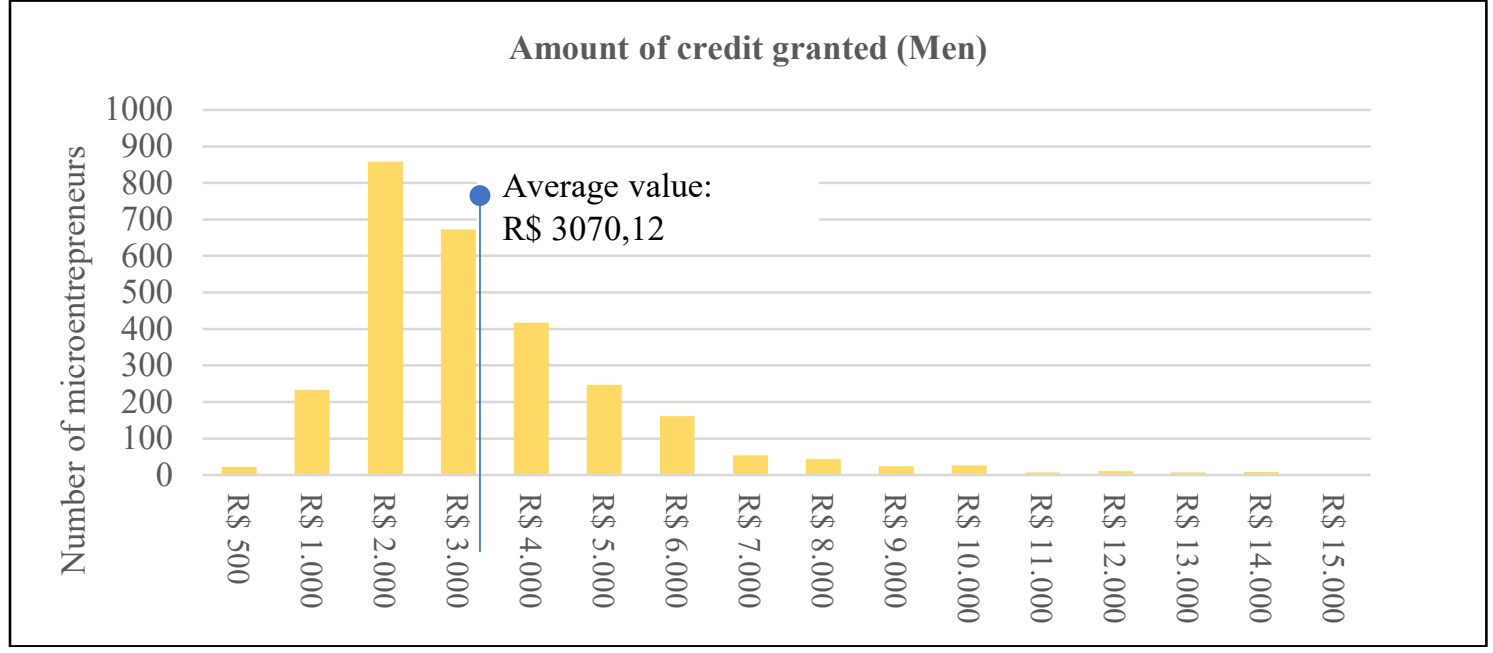

Figure 10. Amount of credit amount granted to male microentrepreneurs.

\section{Revenue}

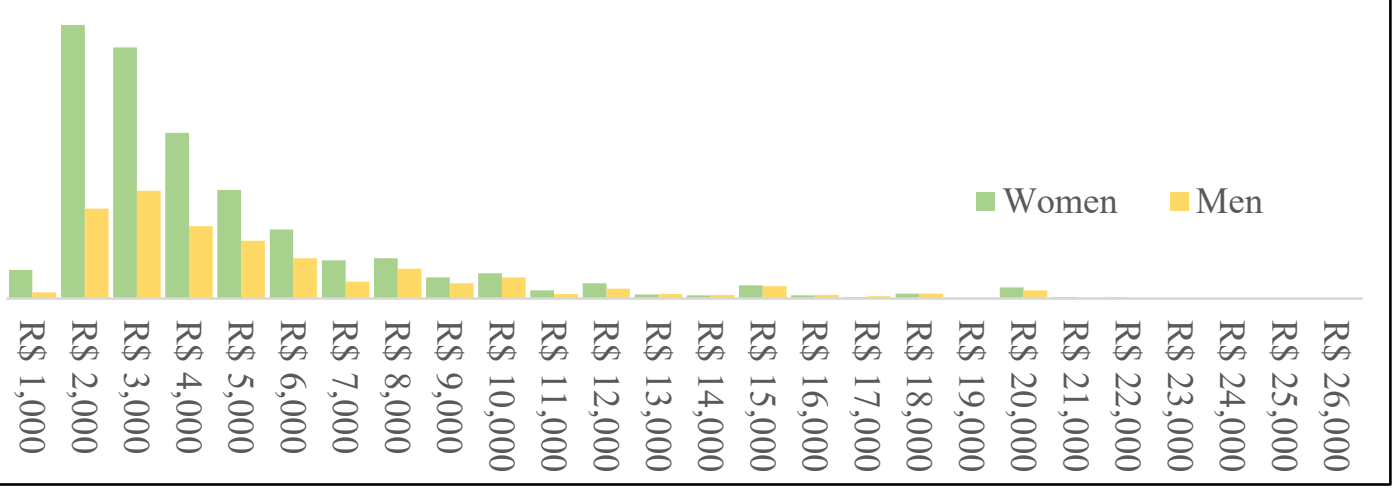

Figure 11. Revenue comparison between men and women. 


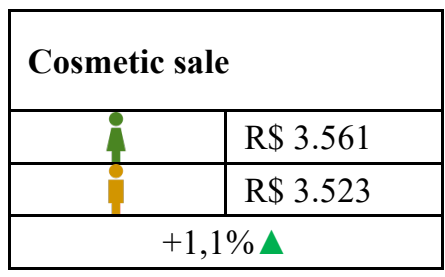

\section{Clothing business}

\begin{tabular}{|c|c|}
\hline 4 & $\mathrm{R} \$ 5.113$ \\
\hline & $\mathrm{R} \$ 5.285$ \\
\hline \multicolumn{2}{|c|}{$-3,3 \% \nabla$} \\
\hline
\end{tabular}

\begin{tabular}{|c|c|}
\hline \multicolumn{2}{|l|}{ Cafeteria } \\
\hline & $\mathrm{R} \$ 4.396$ \\
\hline & $\mathrm{R} \$ 5.148$ \\
\hline & $-14,6 \% \nabla$ \\
\hline
\end{tabular}

\begin{tabular}{|c|c|}
\hline \multicolumn{2}{|c|}{$\begin{array}{c}\text { Jewerly and accessories } \\
\text { business }\end{array}$} \\
\hline & $\mathrm{R} \$ 3.373$ \\
\hline & $\mathrm{R} \$ 4.573$ \\
\hline & $-26,2 \% \nabla$ \\
\hline
\end{tabular}

\begin{tabular}{|c|c|}
\hline \multicolumn{2}{|l|}{ Restaurants } \\
\hline & $\mathrm{R} \$ 6.993$ \\
\hline & $\mathrm{R} \$ 9.209$ \\
\hline$-24,1 \% \nabla$ \\
\hline
\end{tabular}
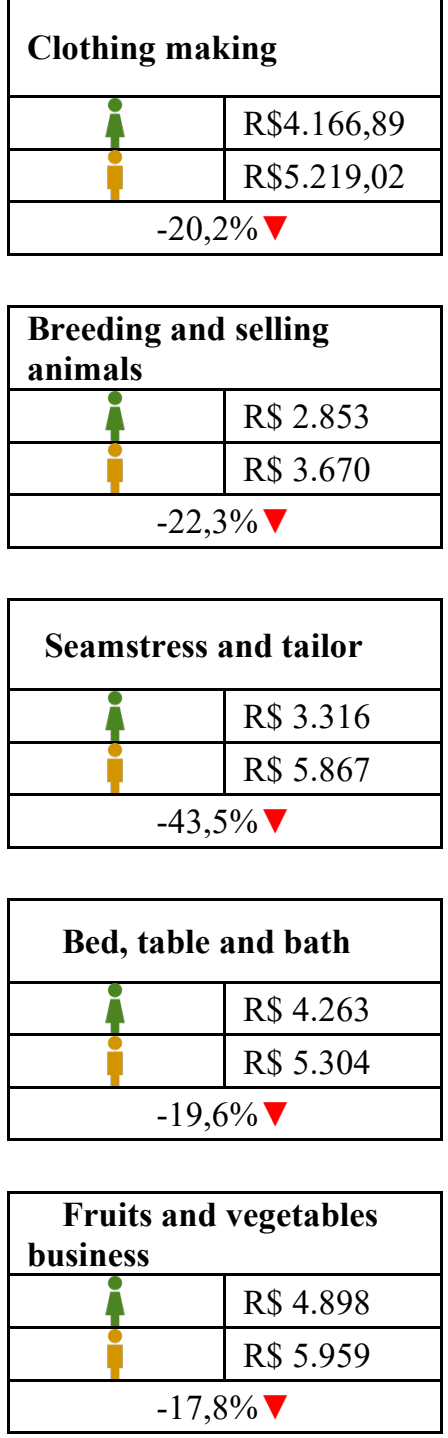

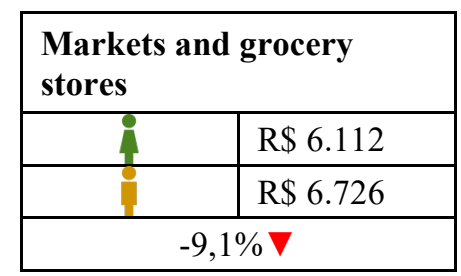

Beauty salons, manicures, pedicures

\begin{tabular}{|c|c|}
\hline 4 & $\mathrm{R} \$ 3.700$ \\
\hline & $\mathrm{R} \$ 3.436$ \\
\hline \multicolumn{3}{|c|}{$+7,7 \% \Delta$} \\
\hline
\end{tabular}
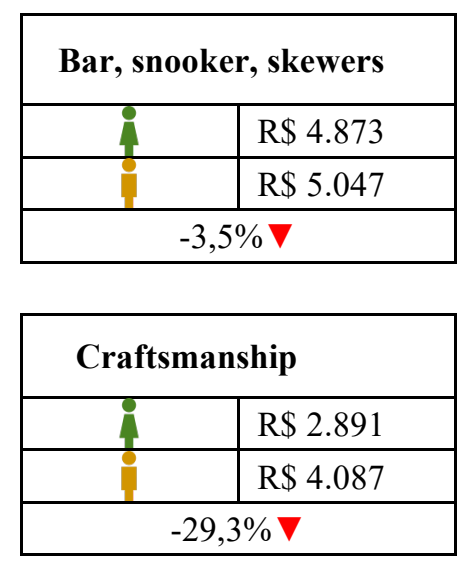

\begin{tabular}{|c|c|}
\hline \multicolumn{2}{|c|}{$\begin{array}{l}\text { Faction of pieces in } \\
\text { jeans }\end{array}$} \\
\hline & $\mathrm{R} \$ 4.737$ \\
\hline & $\mathrm{R} \$ 5.448$ \\
\hline$-13,1 \% \mathbf{\nabla}$ \\
\hline
\end{tabular}

Figure 12. Revenue disparity between male and female microentrepreneurs by industry.

\section{PART II - Methodology}

To assess the impact from microcredit on microentrepreneurs, we chose revenue as a proxy. The declared revenue was collected in two different moments. First, during the process of evaluation for the concession of credit. Then, after a few months, it was collected once again for those microentrepreneurs who had completed the payment of their installments and requested a credit renewal. Therefore, we are able to compare revenue "before" and "after" a certain period of time, for each microentrepreneur. This group of microentrepreneurs will be referred to as the treatment group.

In order to do a proper comparison, we also considered a control group, that is, a group of microentrepreneurs that did not receive any credit at all. We used as a control group the set of microeentrepreneurs who applied for credit in two different moments. At first, he or she requested credit but, for diverse reasons, the loan was not approved. At this stage, all necessary information about that microentrepreneur was collected. In a second moment, if the microentrepreneur reapplies for credit, all the necessary information will be collected again. Therefore, we are able to 
compare revenue "before" and "after" a certain period of time, for these microentrepreneurs in the control group too. It is worth mentioning that, as credit policy, an entrepreneur can only reapply for credit after two months.

By comparing these two groups, we can validate whether the impact generated by microcredit actually existed or not in the treatment group (INSPER, 2020). In our study, the treatment group contains 8724 microentrepreneurs and the control group control contains 4270 microentrepreneurs. This difference occurs because many microentrepreneurs, after being rejected for a loan, do not reapply for credit in the future. Despite being a smaller sample, the control group has some characteristics that are very similar to those of the treatment group, such as geographic distribution, average loan ticket and interest rates. Also, the distribution curves of the revenue for both groups presented very similar shapes, as shown in Figure 13. Thus, we considered these two groups fairly comparable.

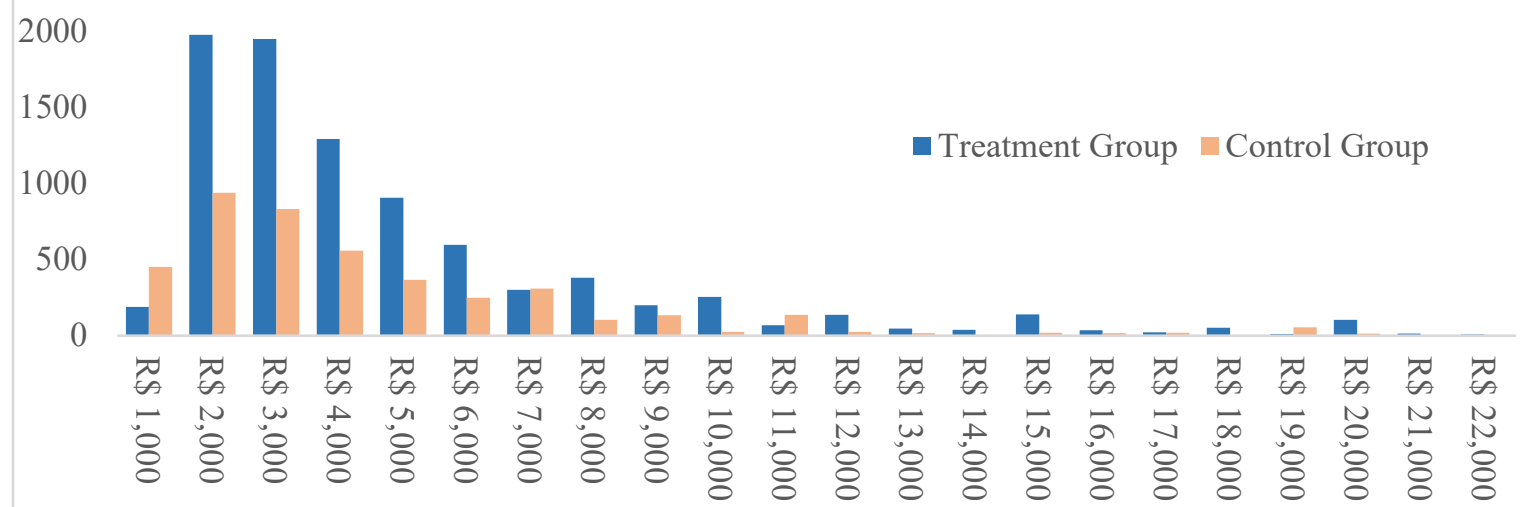

Figure 13. Distribution of Average Revenue for the treatment and control groups.

The average revenue for the two groups, before and after, are shown in Figure 14. Note that there is an increase in the revenue of the treatment group. Our goal here is to assess whether this increase was caused or not by the microcredit offer, using a $95 \%$ confidence level.

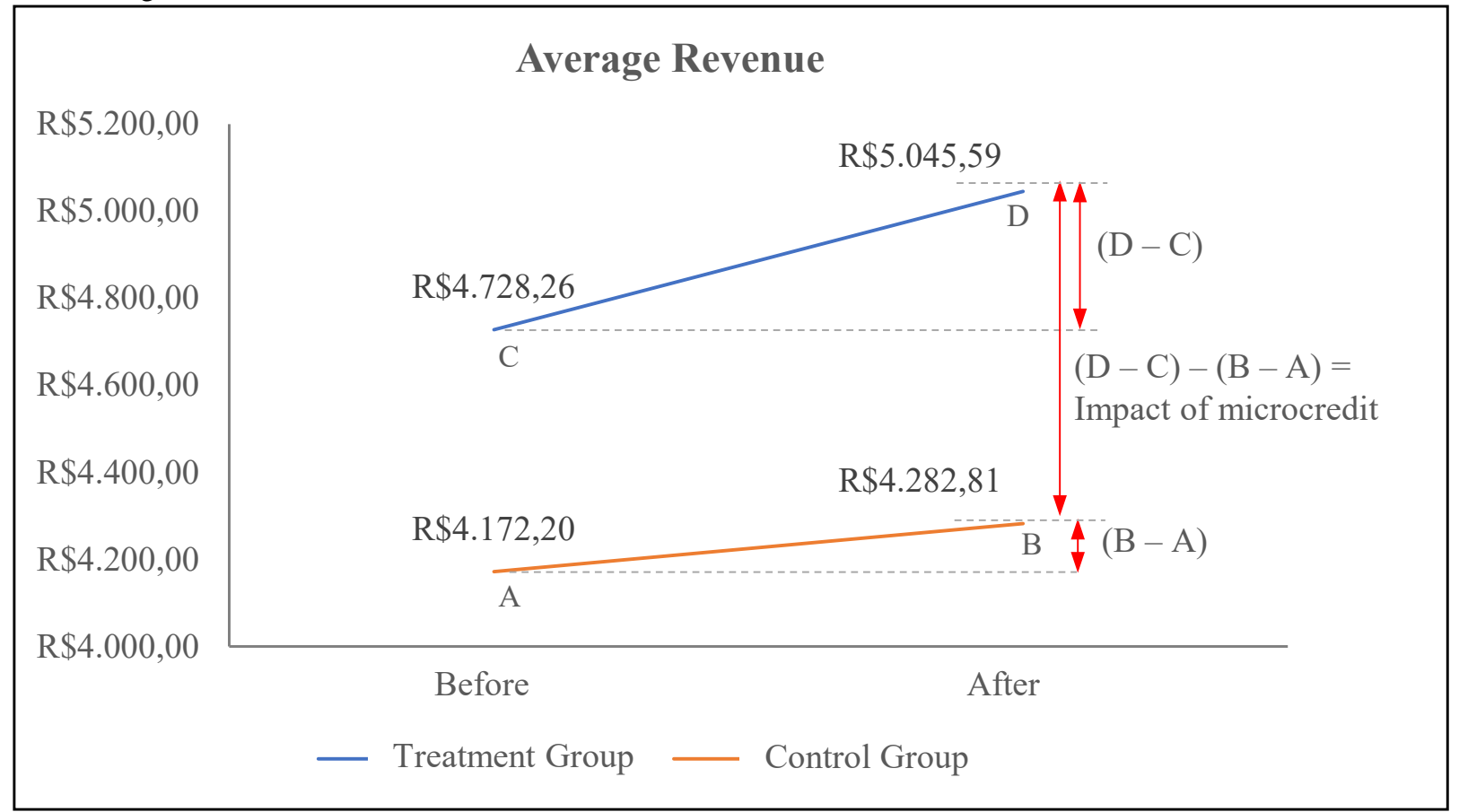

Figure 14. Average revenue of the treatment and control groups, before and after. 
The method used to compare the treatment and control groups is called DiD (differences in differences) (ANGRIST, 2009) and can be extracted from Figure 14 and schematized according to Figure 15.

\begin{tabular}{|l|l|l|l|}
\hline & Before & After & Differences \\
\hline Control Group & A & B & B-A \\
\hline Treatment Group & C & D & D-C \\
\hline Differences & C-A & D-B & (D-C)-(B-A) \\
\hline
\end{tabular}

Figure 15. Scheme of differences in differences.

\section{Part II - Results}

Our first goal is to determine if the microcredit did or did not impact the revenue of microentrepreneurs, regardless of gender. The DiD method can be represented using a multivariate regression shown in Equation 1, in which $\mathrm{Y}$ represents the mean of the studied variable. In our case, Y represents the revenue of the microentrepreneur.

Although the process to obtain the equation will not be discussed in this article, a brief explanation of the regression equation used in this work is shown in Equation 2.

Equation 2: Regression equation to estimate the impact of microcredit for microentrepreneurs.

where,

$$
Y=a+b_{1} \times D_{1}+b_{2} \times D_{2}+b_{3} \times D_{1} \times D_{2}+e
$$

$\boldsymbol{a}$ : constant.

$b_{1}, b_{2}, b_{3}$ : coeficients.

$\boldsymbol{e}:$ error of the regression model.

$\boldsymbol{D}_{\mathbf{1}}$ : dummy variable that indicates control group $(=0)$ or treatment group $(=1)$.

$\boldsymbol{D}_{2}$ : dummy variable that indicates before $(=0)$ or after $(=1)$.

$\boldsymbol{D}_{1} \times \boldsymbol{D}_{2}$ : dummy variable that indicates the impact generated by the two variables $\boldsymbol{D}_{\mathbf{1}}$ and $\boldsymbol{D}_{\mathbf{2}}$ combined.

The result of the regression is shown in Table 2.

Table 2. Multivariate regression statistics to verify the impact of microcredit on the entrepreneurs who had access to it. Result generated via MS Excel.

\begin{tabular}{lc}
\hline \multicolumn{2}{l}{ Regression Statistics } \\
\hline Multiple R & 0,08847993 \\
R-Square & 0,0078287 \\
Adjusted & R- \\
Square & 0,00771415 \\
Standard Error & 3798,69471 \\
Observation & 25988 \\
\hline
\end{tabular}

ANOVA

\begin{tabular}{lllll} 
gl & SQ & MQ & F & Signif. F \\
\hline
\end{tabular}




\begin{tabular}{|c|c|c|c|c|c|}
\hline Regression & 3 & $\begin{array}{l}295854185 \\
2\end{array}$ & 986180617 & 68,341999 & $\begin{array}{l}5,1541 \mathrm{E}- \\
44\end{array}$ \\
\hline Residue & 25984 & $\begin{array}{l}3,7495 \mathrm{E}+1 \\
1\end{array}$ & 14430082 & & \\
\hline Total & 25987 & $\begin{array}{l}3,7791 \mathrm{E}+1 \\
1\end{array}$ & & & \\
\hline
\end{tabular}

\begin{tabular}{lllllllll}
\hline & $\begin{array}{l}\text { Coefficient } \\
\text { S }\end{array}$ & Std Error & Stat t & P-value & $\begin{array}{l}95 \% \\
\text { lower }\end{array}$ & $\begin{array}{l}95 \% \\
\text { higher }\end{array}$ & $\begin{array}{l}\text { Lower } \\
95.0 \%\end{array}$ & $\begin{array}{l}95 \% \\
\text { higher }\end{array}$ \\
\hline Intersection & 4172,20 & 58,13 & 71,77 & 0,0000 & 4058,26 & 4286,14 & 4058,26 & 4286,14 \\
Treatment (D1) & 556,06 & 70,95 & 7,84 & 0,0000 & 417,00 & 695,12 & 417,00 & 695,12 \\
Time (D2) & 110,61 & 82,21 & 1,35 & 0,1785 & $-50,53$ & 271,75 & $-50,53$ & 271,75 \\
D1 x D2 & 206,72 & 100,33 & 2,06 & 0,0394 & 10,06 & 403,38 & 10,06 & 403,38 \\
\hline
\end{tabular}

The results indicate that the coefficient of the variable D1 x D2 presented a P-value of 0.0394 , indicating that the level of maximum confidence for this variable is $1-0.394=96.06 \%$. Therefore, it is reasonable to conclude that there is statistical significance within a $95 \%$ confidence interval. In other words, we have a strong indication that the microcredit concession event for the microentrepreneurs studied had a positive impact on their revenue.

Our second and most important goal is to determine if the microcredit impacted the revenue of male and female microentrepreneurs differently. For this, we added a gender variable in the initial model, and we created an additional variable measure to measure the impact of microcredit on women microentrepreneurs. The regression equation with the inclusion of gender is given in Equation 3.

Equation 3: Regression equation to estimate the impact of microcredit for male and female microentrepreneurs.

$$
Y=a+b_{1} \times D_{1}+b_{2} \times D_{2}+b_{3} \times D_{3}+b_{4} \times D_{1} \times D_{2} \times D_{3}+e
$$

where,

a: constant.

$\boldsymbol{b}_{1}, \boldsymbol{b}_{2}, \boldsymbol{b}_{3}, \boldsymbol{b}_{4}$ : coeficients.

$\boldsymbol{e}$ : error of the regression model.

$D_{1}$ : dummy variable that indicates control group $(=0)$ or treatment group $(=1)$.

$\boldsymbol{D}_{2}$ : dummy variable that indicates before $(=0)$ or after $(=1)$.

$\boldsymbol{D}_{3}$ : dummy variable that indicates gender male $(=0)$ or gender female $(=1)$.

$\boldsymbol{D}_{\mathbf{1}} \times \boldsymbol{D}_{\mathbf{2}} \times \boldsymbol{D}_{\mathbf{3}}$ : dummy variable that indicates the impact of the three variables $\boldsymbol{D}_{\mathbf{1}}, \boldsymbol{D}_{\mathbf{2}}$ and $\boldsymbol{D}_{\mathbf{3}}$ combined.

The result of the regression is shown in Table 3 .

Table 3. Multivariate regression statistics to verify the impact of microcredit on women entrepreneurs who had access to it. Result generated via MS Excel.

\begin{tabular}{lc}
\hline \multicolumn{2}{l}{ Regression Statistics } \\
\hline Multiple R & 0,1258 \\
R-Square & 0,0158 \\
Adjusted & R- \\
Square & 0,0157 \\
Standard Error & 3783,43 \\
Observation & 25988 \\
\hline
\end{tabular}

ANOVA 


\begin{tabular}{llllll}
\hline & gl & SQ & MQ & F & Signif. F \\
\hline Regression & 4 & $5,981 \mathrm{E}+09$ & $1,495 \mathrm{E}+09$ & 104,45934 & $2,01715 \mathrm{E}-$ \\
& & & & & 88 \\
Residue & 25983 & $3,719 \mathrm{E}+11$ & 14314310 & & \\
Total & 25987 & $3,779 \mathrm{E}+11$ & & & \\
\hline
\end{tabular}

\begin{tabular}{|c|c|c|c|c|c|c|c|c|}
\hline & $\begin{array}{l}\text { Coefficient } \\
\mathrm{s}\end{array}$ & Std Error & Stat $\mathrm{t}$ & P-value & $\begin{array}{l}95 \% \\
\text { lower }\end{array}$ & $\begin{array}{l}95 \% \\
\text { higher }\end{array}$ & $\begin{array}{l}\text { Lower } \\
95.0 \%\end{array}$ & $\begin{array}{l}95 \% \\
\text { higher }\end{array}$ \\
\hline Intersection & 4017,57 & 54,77 & 73,3494 & 0,0000 & 3910,2146 & $\begin{array}{l}4124,93 \\
12\end{array}$ & $\begin{array}{l}3910,21 \\
46\end{array}$ & $\begin{array}{l}4124,93 \\
12\end{array}$ \\
\hline Treatment (D1) & 565,42 & 52,68 & 10,7337 & 0,0000 & 462,1721 & $\begin{array}{l}668,672 \\
7\end{array}$ & $\begin{array}{l}462,172 \\
1\end{array}$ & $\begin{array}{l}668,672 \\
7\end{array}$ \\
\hline Time (D2) & 113,60 & 51,70 & 2,1972 & 0,0280 & 12,2625 & $\begin{array}{l}214,931 \\
9\end{array}$ & 12,2625 & $\begin{array}{l}214,931 \\
9\end{array}$ \\
\hline Gender (D3) & 454,72 & 60,23 & 7,5500 & 0,0000 & 336,6691 & $\begin{array}{l}572,766 \\
5\end{array}$ & $\begin{array}{l}336,669 \\
1\end{array}$ & $\begin{array}{l}572,766 \\
5\end{array}$ \\
\hline D1 x D2 x D3 & 629,99 & 100,54 & 6,2663 & 0,0000 & 432,9336 & $\begin{array}{l}827,047 \\
8\end{array}$ & $\begin{array}{l}432,933 \\
6\end{array}$ & $\begin{array}{l}827,047 \\
8\end{array}$ \\
\hline
\end{tabular}

The results show that the coefficient of the variable D1 x D2 x D3 showed a significantly small P-value, indicating that the maximum confidence level for this variable is $1-0.0000 \approx 100 \%$. That is, there is statistical significance within a $95 \%$ confidence interval. So we have a pretty strong indication that the event of granting microcredit to microentrepreneurs women had a positive impact on their earnings. From these indications, we then calculate the annualized increase in the average turnover of microentrepreneurs for the treatment group. The result is shown in Table 3. We observed that the average annualized earnings for women were consistently higher than that of men in all evaluated states.

Table 4. Growth in average revenue for women compared to men, after access to microcredit.

\begin{tabular}{|c|c|c|c|}
\hline Location & Gender & Increase in revenue & Women vs. men \\
\hline \multirow{2}{*}{$\begin{array}{l}\text { Ceará } \\
\text { State }\end{array}$} & Women & $19.03 \%$ & \multirow{2}{*}{$26.38 \% \Delta$} \\
\hline & Men & $15.06 \%$ & \\
\hline \multirow{2}{*}{$\begin{array}{l}\text { Maranhão } \\
\text { State }\end{array}$} & Women & $19.58 \%$ & \multirow{2}{*}{$9.20 \% \Delta$} \\
\hline & Men & $17.93 \%$ & \\
\hline \multirow{2}{*}{$\begin{array}{l}\text { Paraíba } \\
\text { State }\end{array}$} & Women & $20.69 \%$ & \multirow{2}{*}{$63.05 \% \Delta$} \\
\hline & Men & $12.69 \%$ & \\
\hline \multirow{2}{*}{$\begin{array}{l}\text { Pernambuco } \\
\text { State }\end{array}$} & Women & $20.20 \%$ & \multirow{2}{*}{$55.98 \% \triangle$} \\
\hline & Men & $12.95 \%$ & \\
\hline
\end{tabular}




\section{Conclusion}

This work was motivated by the observation that the number of female microentrepreneurs is significantly larger than male. For this reason, microentrepreneur-oriented microcredit can have a major impact on the empowerment of women and an important role in reducing gender inequality.

In this study, we tried to infer the impact of microcredit on the revenue of microentrepreneurs. Then, our analysis went further to compare the impact for women and for men. To do this, we needed to compare the group of microentrepreneurs who received credit with a control group, which did not have access to credit. Also, to make a comparison between men and women, we needed to measure the impact of microcredit specifically on the female group.

Our regressions show a positive impact on the revenue of those who had access to microcredit in relation to those who did not. Last but not least, regressions show a positive impact for women in comparison to men. The results have shown that the average revenue increase for female microentrepreneurs was $39.37 \%$ higher than that for male, after the microcredit.

\section{Limitations}

The type of analysis done in this research is known to be quite complex in the academic world. Therefore, this work made a few simplifications. First, it is important to emphasize that, as pairing between the observable characteristics of the treatment group and the control group was not perfect, it is perfectly possible that we have some level of bias in the data. Second, our regression methodology does not take into account control variables that could affect the dependent variable (revenue), such as education level and previous experiences of the microentrepreneurs. Finally, the time horizon is relatively short.

\section{Discussion}

It is of great importance that the players in the microcredit market, including private companies and government, consider the impact of gender in their policies and methodologies. As future steps, our working group intends to further increase the volume of analyzed data, the time-space, and improve the methodology for group pairings. For now, the initial indications already suggest that the microcredit impact on female microentrepreneurs must indeed be positive, consistent and greater than the impact for male.

\section{Acknowledgements}

We register here our thanks to Avante.com.vc for providing access to real microcredit data and unconditionally supporting this work. Also, we would like to thank Gilberto Ribeiro, from Insper. His Master Thesis was of great value, and his knowledge, encouragement and revision were essential to this work.

\section{References}

ANGRIST, J. D .; PISCHKE, J. S. Mostly harmless econometrics: An empiricist's companion. 1.ed. Princeton University Press, 2009. 373p.

CUNHA, R. N., ONOZATO, E., GUIMARÃES, M. L., JUNIOR, P. A. B., GRECO, S. M. S. S., SOUZA, V. L. Entrepreneurship in Brazil. Global Entrepreneurship Monitor. 1. ed. Curitiba: IBQP, 2018. 174p. 
FILHO, G. R. O. Impacts of microcredit: A quasi-experimental approach with entrepreneurs from the Northeast of Brazil. 2019. 55f. Dissertation (Professional Master in Economics) $\neg$ - Department of Economics, Insper, São Paulo, 2019.

ALESP. Government of the State of São Paulo, Legislative Assembly. The importance of microcredit in generating employment and income. Available at:

$<$ https://www.al.sp.gov.br/noticia/?id=271622\#: :text=O\%20microcr\%C3\%A9dito\%20induz\%20ao\%20desenvolvi mento,de\%20garantia\%20bem\% 20more\% 20access\% C3\% ADvel>. Accessed on: June 15, 2020.

ILO. Women Swell Ranks of Working Poor, says ILO. Available at: <https:/www.ilo.org/global/about-theilo/newsroom/news/WCMS_008066/lang--en/index.htm\#: :text=\%22The\%20bottom\%20line $\% 20$ is \% 20that, author $\%$ 20of $\%$ 20the $\%$ 20ILO $\%$ 20report. \& Text $=$ Women $\%$ 20make $\%$ 20up $\%$ 20nearly $\%$ 2070, percent $\%$ 20of $\%$ 20the \% 20world's\% 20illiterate>. Accessed on: June 15, 2020.

INSPER. Socio-environmental impact assessment guide for use in impact projects and investments: general guide with a focus on verification of additionality. - 4th. ed. - São Paulo: Insper, 2020.

POMERANS, Dina. The promise of microfinance and women's empowerment: what does the evidence say ?. 2014. 24f. Research (Ph.D. in Economics) - Harvard Business School, Harvard University, Boston. 2014.

SEBRAE. Female Entrepreneurship in Brazil. Special Report - São Paulo: Sebrae - Strategic Management Unit, 2019.

ALESP, Legislative Assembly of the State of São Paulo. The importance of microcredit in generating employment and income. Available at:

<https://www.al.sp.gov.br/news/?id=271622\#: :text=O\%20microcr\%C3\%A9dito\%20induces\%20to\%20developme nt, from\%20guarantee\%20well\%20plus\%20access\%C3\%ADvel>. Accessed on: November 15, 2020. 